\title{
THE CENTURY OF WOMEN
}


This page intentionally left blank 


\section{THE CENTURY OF WOMEN}

\section{Representations of Women in Eighteenth-Century Italian Public Discourse}

Rebecca Messbarger 
www.utppublishing.com

(C) University of Toronto Press Incorporated 2002

Toronto Buffalo London

Printed in Canada

ISBN 0-8020-3652-X

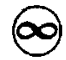

Printed on acid-free paper

Toronto Italian Studies

\section{National Library of Canada Cataloguing in Publication}

Messbarger, Rebecca

The century of women : representation of women in eighteenth-century Italian public discourse / Rebecca Messbarger.

(Toronto Italian Studies)

Includes bibliographical references and index.

ISBN 0-8020-3652-X

1. Women - Italy - History -18 th century. 2. Women - Italy -

History -18 th century - Sources. 3. Women - Education - Italy History -18 th century. 4. Women - Education - Italy - 18th century Sources. I. Title. II. Series.

This volume was published with financial assistance from the Division of Arts and Sciences at Washington University.

University of Toronto Press acknowledges the financial assistance to its publishing program of the Canada Council for the Arts and the Ontario Arts Council.

University of Toronto Press acknowledges the financial support for its publishing activities of the Government of Canada through the Book Publishing Industry Development Program (BPIDP). 
For Sam, Graham, and Max 
This page intentionally left blank 